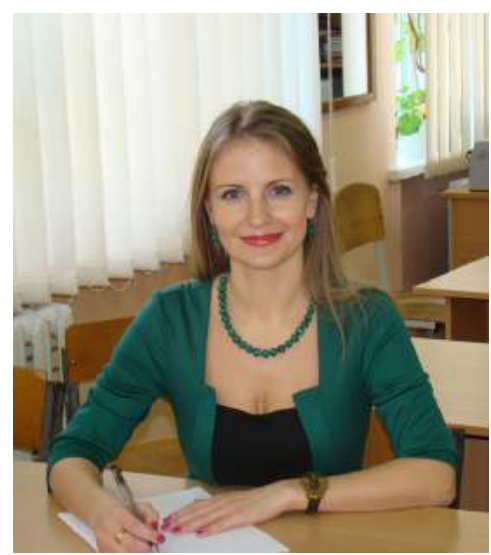

Тетяна Лесіна,

кандидат педагогічних наук, доцент кафедри загальної педагогіки, дошкільної та початкової освіти, Ізмаїльський державний гуманітарний університет (м. Ізмаїл, Україна)

Tetyana Lesina,

$\mathrm{PhD}$ in Education, Associate Professor, Department of General Education, Pre-school and Primary Education, Izmail State University of Humanities (Izmail, Ukraine) lessina_tanya@ukr.net ORCID ID 0000-0002-7923-2247

Удк 378.01.3 - 51:372.2]: 316.42 (043. 30)

\title{
КРЕАТИВНІСТЬ ЯК ПЕРЕДУМОВА ПРОДУКТИВНОЇ ДІЯЛЬНОСТІ МАЙБУТНЬОГО ВИХОВАТЕЛЯ ЩОДО ФОРМУВАННЯ СОЦІАЛЬНИХ НАВИЧОК У ДОШКІЛЬНИКІВ
}

Анотація. У статті акцентовано увагу на домінантах креативної педагогіки як методологічної основи вдосконалення професійної підготовки майбутніх педагогів-дошкільників. Зазначено, що креативні досягнення фахівця перебувають у площині систематизації його наукових уявлень про базові категорії креативної педагогіки (творчість, креативний продукт, оригінальність, креативний клімат тощо).

Метою статті $€$ аргументувати на основі узагальнення наукового фонду з проблеми вдосконалення професійної підготовки майбутніх вихователів актуальність здатності студентів до формування у дошкільників соціальних навичок, зосередивши увагу на деяких ресурсах, пов'язаних із креативністю освітнього середовища сучасного вишу.

Розглянуто один із сегментів професійної діяльності майбутнього вихователя - розвиток навичок у дітей передшкільного віку. Синтезовано сучасні наукові уявлення щодо феноменології соціальної навички. На основі саморефрлексії досвіду обґрунтовано стратегію продуктивної підготовки майбутнього вихователя до формування у дошкільнят соціальних навичок, що базується на постулатах креативної педагогіки.

Методологічні орієнтири дослідження репрезентує теоретичний концепт, що пояснює досліджене явище у контексті компетентнісного (Дж. Равен) та особистісно-діяльнісного (І. Зимня) підходів.

Висновки. Формування креативної особистості майбутнього педагога-дошкільника в умовах вищої школи $є$ не самоціллю, а суттєвою передумовою їх успішної професійної підготовки.

Ключові слова: дошкільник, креативність, майбутній педагог-дошкільник, соціальна навичка.

\section{CREATIVITY AS A CONDITION OF THE FUTURE TEACHER'S PRODUCTIVE ACTIVITY FOR THE FORMATION OF NURSERY TEACHERS' SOCIAL SKILLS}

Abstract. In the article, attention has been paid to the creative dominant pedagogy as a methodological basis of improvement of future nursery teachers' vocational training in the conditions of higher pedagogical school. It has been noted that the creative achievements of the expert lie in the systematization of scientific views on the basic categories of creative pedagogy (creativity, creative product, originality, creative climate, etc.).

The segment of professional activity of the future teacher of a preschool educational institution as the development of nursery teachers' social skills has been considered. Modern scientific knowledge about the phenomenology of social skills has been synthesized. The essence of the basic laws that determine social skills development trends as a personal significant quality at the stage of preschool childhood has been disclosed. In modern conditions, when pre-school education gained the status of the initial stage of continuing education of the individual, the problem of training competitive preschool teachers is brought into focus. Scientists that directly or indirectly investigate the above issue are united in the judgment that it is the readiness of the preschool institution teacher that is an important condition for his ability to develop pre-school maturity of the child.

On the basis of self-reflection of University experience productive strategy for vocational training of students - future preschool teachers in the aspect of the nursery teachers' social skills productive formation has been well-grounded. Some practically oriented approaches to implementing the leading idea of the developed strategy: from the creativity of the nursery teacher to the creative personality of preschoolers have been reflected.

The methodological reference-points of research are represented by theoretical concept that explains the investigated phenomenon in the context of competence (J. Raven) and personality-oriented (I. Zimniaya) approaches.

The conclusion of the article reflects the basic idea: forming of creative personality of future preschool teacher in the conditions of higher school is not end in itself, and substantial pre-condition of his successful professional formation.

Prospects for further research of the identified problem are associated with the development of the model of the pedagogical system of the future preschool teacher's vocational training in the given domain.

Keywords: a nursery teachers', creativity, a future preschool teacher, social skills. 


\section{ВСТУП}

Постановка проблеми. Для сучасних наукових уявлень про ресурси вищої освіти України у ракурсі підвищення якості професійної підготовки майбутніх фахівців, здатних реалізувати своє соціально-професійне призначення та особистісну роль відповідно до євроінтеграційних тенденцій та швидкоплинності змін, $€$ характерний акцент на творчості (І. Бех, С. Ганаба, В. Моляко, С. Сисоєва, І. Предборська та ін.), а це вимагає нової оцінки доробку попередників (С. Гессен, М. Бердяєв, М. Монтень, С. Франк та ін.). Так, намагаючись дослідити творчість як концептуальну складову якості вітчизняної освіти, науковці здебільшого єдині у визнанні важливості долучати студентів до творення знань, здобування освіти впродовж життя, а це процес творчий, що потребує нового погляду щодо вибору стратегії опанування креативної педагогіки [6, с. 89-90].

Аналіз останніх досліджень і публікацій. Ключове поняття «креативність» у психології творчості було введено Дж. Гілфордом, нині воно тлумачиться по-різному. Наприклад, в англомовній літературі воно здебільшого подане як «творчість», «здібність творити». Так, у фундаментальнихдослідженнях, які віддзеркалюють порівняльну характеристику існуючих підходів до визначення креативності, міститься не лише обґрунтування доцільності розглядати ії̈ як функцію цілісної особистості, яка залежить від інтегрованого поєднання інтелектуальних здібностей і духовності (В. Шадриков), як синоніми «творче» та «креативне» стосовно мислення (Д. Богоявленська), а й розведення понять «творчість» та «креативність» за процесуально-результативним (творчість) та суб'єктивнорезультативним (креативність) аспектами [2].

Отож, креативні досягнення особистості неможливі без спеціальних знань з проблеми креативності (зокрема тієї істини, що продукт креативного процесу обов'язково вирізняється оригінальністю, осмисленістю, виразністю і економією ресурсів). Для виявлення і розвитку креативності принципово вагомим $є$ «креативний клімат» (вислів Д. Треффрінджера) освітнього середовища - стимул мотивації, що виконує визначальну роль у креативності. Означене визнано постулатами саме креативної педагогіки.

Отож у пошуках підходів до вдосконалення професійної підготовки майбутніх педагогів-дошкільників до певного сегмента фрахової діяльності доцільно творчо реалізувати ідеї креативної педагогіки.

META I ЗАВДАННЯ ДОСЛІДЖЕННЯ: на основі узагальнення наукового фонду 3 проблеми вдосконалення професійної підготовки майбутніх вихователів аргументувати актуальність здатності студентів до фрормування у дошкільників соціальних навичок, зосередивши увагу на деяких ресурсах, пов'язаних із креативністю освітнього середовища сучасного вишу.

МЕТОДИ ДОслІДЖЕНня: аналіз філософських, психологічних, педагогічних праць; зіставлення та узагальнення різних поглядів на проблему; апробація стратегії підготовки майбутніх педагогів-дошкільників.

\section{РЕЗУЛЬТАТИ ДОСЛІДЖЕННЯ}

Аналіз наявних фундаментальних досліджень, присвячених розширенню уявлень про феноменологію професійної підготовки майбутніх педагогів-дошкільників в умовах вищої школи (Ю. Волинець, С. Гаврилюк, О. Листопад, Ю. Руденко) засвідчує, що ще й досі поза увагою залишається питання ресурсів креативної педагогіки щодо освітнього середовища сучасного вишу. До того ж недооціненим залишається серед науковців такий сегмент готовності випускника-бакалавра, який набув у виші спеціальність «Дошкільна освіта», як формування у дітей передшкільного віку саме соціальних навичок. Практиками ж дошкілля констатується потреба у науково обґрунтованих рекомендаціях у зазначеному плані [5, с. 3].

3 чим ми пов'язуємо значущість формування у дитини, зокрема передшкільного віку, саме соціальних навичок? Насамперед із вагою «соціального» в особистості, що набуває виняткового значення в сучасну «інформаційну» епоху, де домінування інтернет-технологій позначилося на зсуві духовності молодого покоління, на модифікації фрорм суспільних зв'язків, на розширенні «безособистісно-центрованого» спілкування та «соціокультурного егоїзму». Отож, як зазначають науковці (Т. Алексєєнко, А. Брушлинський, Н. Лавриненко, А. Малько, А. Рижанова), особливої актуальності набувають такі соціально-виховні технології, які сприятимуть більшій позитивній динаміці розвитку соціального в особистості (поряд з індивідуальністю), де вищеокреслене виступає одночасно і в якості мети, і як інтегральний результат соціального виховання.

Як відомо, поняття «соціальність» було введене у науковий обіг понад сто років тому, завдячуючи доробку і фрілософів, і соціологів, і психологів у цьому напрямку. Деякі науковці, зокрема А. Рижанова, вважають суттєвим внесок представників фрранцузької соціологічної школи (В. Дуаз, Е. Дюргейм, Д. Жодле та ін.) в осмислення соціальності як «суспільної свідомості»; С. Рубінштейна, Е. Фромма та ін. у визначенні основи розвитку соціальності - спільної практичної діяльності, де «на внутрішньому рівні» суб'єктом виступає взаємодія індивіда та спільноти людей; М. Бахтіна, Л. Виготського та ін., які вважають провідними фракторами соціального в людині, зокрема мову; К. Абульханової-Славської через поглиблення психологічних уявлень про такі складові соціальності, як соціальну компетентність, соціальну активність, соціальну позицію тощо; А. Брушлинського, який довів нетотожність понять «соціальний» і «громадянський»; фрілософрів (М. Бубер, В. Вернадський, Р. Рорті та ін.) стосовно контекстності соціальної етики щодо поняття «соціальне» - йдеться про вагу таких складових, як толерантність, взаєморозуміння, «культура досягнень злагоди» у явищі «соціальна єдність».

Оскільки соціальність - комплексна характеристика дитини дошкільного віку як соціального суб'єкта, то вона формується насамперед у мікросоціумі, а відтак відповідно обґрунтованим є такий висновок: принципово важливо, щоб «сімейна соціальність» не була формальною або зовсім відсутньою (наприклад, у наслідок набуття батьками дошкільника статусу трудових мігрантів у зарубіжжі з «передаванням» батьківських обов'язків родичам). Довідкові джерела трактують «соціальність» будь-якого соціального суб'єкта як динамічне явище, хоча його розвиток «не є безумовно поступовим»; визначають і форми (сімейна, громадянська, регіональна та ін.), і рівні (біологічний, фрізичний, духовний, душевний) соціальності [3, с. 100-101]. Дійсно, як засвідчує практика, сучасне інформаційне суспільство породжує потребу в нових формах «соціального» в соціальних суб'єктах, актуалізуючи, з одного боку, спрямованість особистості на самовдосконалення власної соціальності 
через активне і відповідальне ставлення до соціального середовища, а з іншого - посилюючи вагу найвищого, духовного, рівня соціальності через прискіпливий вибір системи ціннісних орієнтацій, активну їх реалізацію суб'єктом «з повною відповідальністю за наслідки», що позначається на соціумі.

Ми акцентували дослідницьку увагу на «зрізі» дій, що в результаті багаторазового виконання дітьми дошкільного віку набувають автоматизованого характеру, тобто на соціальних навичках.

Аналіз довідкових джерел щодо філософського, психологічного, суто педагогічного аспектів означеного явища засвідчує про суттєві його ознаки.

Так, фрілософська наука (А. Андрущенко, М. Горлач, В. Шинкарук та ін.) трактує соціальні навички здебільшого через світовідношення у контексті таких близьких понять, як типологія соціального освоєння на соціально-фрілософському рівні (духовне соціальне освоєння, практичне, духовно-практичне) та соціальний інтелект (на противагу фрормам соціопатії і соціального паразитизму) - громадянської чесноти, що віддзеркалює рівень розуміння особистістю суспільства. До зазначеного додамо: якщо соціальний інтелект інтерпретувати через такий термін аналітичної філософії, як «етос» (що означає характер особи чи об'єкта), то йдеться про шанобливе ставлення особистості до суспільства, тобто соціальний етос, обов'язок, «готовність долучитися до громадянського життя» [8, с. 599].

Довідкова психологічна література пояснює своєрідність навички як автоматизованої дії, що дозволяє виконувати певні соціальні дії точно, впевнено, без зайвих нервово-психічних і фрізичних затрат. При цьому контекстним розглядається процес соціалізації особистості. Отож можна припустити, що за сформованості у дошкільників соціальних навичок їхня позитивна соціалізація (з лат. - суспільний) здійснюється успішно. До того ж довідкові джерела містять і узагальнену характеристику етапності формування будь-якої навички: від сприймання особистістю зразка виконання, зокрема соціальної дії, фрормування «нервової моделі» такої дії та ії первісного виконання - до багаторазового виконання, де результатом слугує часткова автоматизація окресленої дії. Отож логічним є психологічне узагальнення про те, що у ракурсі означеної етапності увага особистості «переміщується з процесу виконання дії на іï результат», чим зайві рухи знімаються, а сенсорний контроль «поступово передається м'язовому контролю» [7, с. 215]. У такий спосіб і досягається сорормованість навички - необхідного компонента, зокрема соціального уміння особистості, засвоєння соціального досвіду через спільну діяльність (наприклад, старших дошкільників із однолітками), спілкування, соціальне виховання і навчання. Слід зауважити, що психологи (В. Зінченко, Б. Мещеряков) пов'язують навички із так званою «процедурною пам'яттю» особистості, вважаючи, що здатність особистості до формування і відтворення навички правомірно розглядати як важливий показник загальних їі інтелектуальних можливостей і збереженість у повній цілості. До того ж стверджується, що навичка є «добре сформованою дією», у динамічній структурі якої варто розрізняти і когнітивні, і виконавчі (моторні) компоненти та корекційні процеси. Отож робиться узагальнення про доцільність створення варіативних умов задля узгодження зв'язків між зазначеними компонентами навички. А це, на наш погляд, принципово важливо з огляду на результативність їх формування.

Спираючись на соціологічну та соціально-педагогічну довідкову літературу, спостерігаємо близькість соціальних навичок і ключових понять соціології та соціальної роботи. Вчені (М. Головатий, М. Панасик, В. Радул) акцентують на розумінні соціальних навичок наближено до поняття «соціальне», виявом якого слугує ставлення особистості до явищ і процесів громадянського життя. Йдеться про автоматизовані дії «слухати інших із розумінням», i «цілеспрямовано спостерігати та інтерпретувати вербальну і невербальну поведінку інших», «отримувати інформацію і збирати факти» щодо соціального буття. Отже, йдеться про «соціальне» в широкому розумінні, що різниться від природного і біологічного.

Враховуючи домінанти креативної педагогіки та психолого-педагогічну природу такого явища, яким є, за висновками сучасних науковців, соціальна навичка особистості дитини передшкільного віку, ми апробували на базі Ізмаїльського державного гуманітарного університету стратегію підготовки майбутніх фахівців.

Принагідно зазначимо, що посилену увагу було приділено формуванню у майбутніх педагогів-дошкільників професійної компетнетності щодо сутності поняття «соціальна навичка» через систематизацію їхніх наукових знань у процесі засвоєння відповідних змістових модулів нормативних навчальних дисциплін та дисциплін за вибором студентів. Йдеться, зокрема, про створення у процесі навчання «креативного клімату», що стимулює «виготовлення студентами, відповідно до навчального модуля, «креативного продукту» (насамперед, виконання різнорівневих завдань на період громадянського-педагогічної практики щодо створення «банку» креативних ситуацій, що віддзеркалють своєрідність соціалізації дошкільнят в умовах дошкільного навчального закладу; виконання індивідуального дослідження за методикою «Завершення малюнків» П.Торренса та ін.). Продуктивними у зазначеному ракурсі виявилась практика заохочення студентів до складаня структурно-логічних схем щодо дефінативно-смислового супроводу навчальних тем відповідного змістового модуля (курс «Дошкільна педагогіка», виконання проблемно-логічних вправ, ініціювання інтерактивних форм навчального діалогу («Мозковий штурм», ділові ігри та ін.). Спонукаючи майбутніх фахівців до вияву оригінальності, запроваджували систему творчих завдань, зокрема в межах курсу «Теорія та методика співпраці ДНЗ з родиною» - дисципліни за вибором студентів» (типу «Подайте у вигляді педагогіого малюнку бар'єри, що перешкоджають вияву креативності дитини у різних типах сім'ї - родини»).

Зауважимо, що в межах розробленої стратегії значну увагу приділяли діагностиці креативності майбутніх вихователів, де контекстом виступав окреслений сегмент їхньої майбутньої професійної діяльності - формування у дошкільнят соціальних навичок. Так, показники сформованості вербальної креативності (кількість асоціацій, оригінальність, унікальність) виявлялися за текстом С.Медніка, а показники невербальної креативності (оригінальність, унікальність) - за текстом П. Торренса.

Докладний аналіз довідкових педагогічних джерел засвідчує доречність низки узагальнень. По-перше, має педагогічний сенс осмислювати соціальні навички дошкільників у площині соціальних цілей сучасної вітчизняної освіти, а саме: принципову важливість для особистості вже на етапі передшкільної освіти становить її підготовленість до життя в суспільстві, до свідомої і комплексної участі у різних видах діяльності, що притаманні людині як соціальній 
істоті, цілісний особистісний розвиток і «всіляке сприяння повнокровному і творчому життю» [1, с. 434], причому із урахуванням своєрідності первинної соціалізації, що пов'язана із феноменологією дитинства та специфікою ситуації набуття соціального досвіду дітьми дошкільного віку. Так, Н. Голованова зауважує, що така ситуація пов'язується, з одного боку, і з випередженням емоційних переживань, зумовлених осмисленням соціального досвіду, а, 3 і ншого - із «серйозною залежністю» дітей від оцінок та авторитету вихователя [4, с. 110-111]. Тому, узагальнює науковець, «дитячий соціальний досвід - це завжди образ реально пережитої ситуації».

По-друге, соціальні навички ще й доцільно тлумачити у контексті понять «соціальність», «соціальна зрілість», «соціально-психологічна компетентність». Водночас необхідно розуміти, що сам термін «соціальні навички» не можна підміняти або замінювати означеними ключовими для сучасної психолого-педагогічної науки поняттями. Наприклад, соціально-психологічна компетентність базовою має здатність до ефективної взаємодії з оточенням; соціальна зрілість особистості віддзеркалює рівень сформованості настанови, етичних якостей, які є достатніми для відповідального виконання соціальних ролей дорослої людини - сформованість соціальних навичок уже на етапі дошкільного дитинства виступає суттєвою передумовою окресленої особистісної якості; з огляду ж на становище дошкільника в суспільстві, зрозумілим є і його соціальний статус - підготовка до самостійного життєвого вибору, де сформовані соціальні навички слугують ще й важливими життєвими навичками.

По-третє, як стверджують науковці ( $Є$. Рапацевич, С. Гончаренко, І. Звєрєва), формування навички відбувається на основі «застосування знань про відповідний спосіб дії шляхом цілеспрямованих планомірних вправлянь»; завдяки навички діяльність стає «продуктивнішою» і відбувається швидше [1, с. 300]. До того ж педагогаминауковцями встановлено, що процес формування будь-якої навички (не є винятком і соціальна) відбувається не стихійно, а за певними законами, а саме: 1) за законом зміни швидкості розвитку навички (навичка швидко вдосконалюється лише за перших повторень, а надалі - уповільнюється); 2) за законом «плато», який психологи пояснюють характером перебудови психіки людини, коли в наслідок більш продуктивних способів діяльності відбувається більш вітчутний «приріст» у розвитку навички; 3) за законом відсутності меж у розвитку навички, який пояснює ресурси підвищення ії продуктивності - за рахунок перебудови в структурі психіки; 4) за законом «затухання навички» через відсутність повтору дій; 5) за законом перенесення навички, що пояснює тенденцію щонайшвидшого вдосконалення навички у такій діяльності, яка за своєю психічною структурою наближена до тієї, у процесі якої сорормовані міцні навички. Отже, беручи до уваги окреслені основні внутрішні зв'язки, що існують між явищами, та обгрунтовуючи їх необхідний розвиток, маємо можливість розширити наукове уявлення про феноменологію саме соціальних навичок дітей дошкільного віку.

\section{ВИСНОВКИ ТА ПЕРСПЕКТИВИ ПОДАЛЬШИХ ДОСЛІДЖЕНЬ}

Отже, формування креативної особистості майбутнього педагога-дошкільника в умовах вищої школи $\epsilon$ не самоціллю, а суттєвою передумовою їхньої успішної професійної підготовки. Провідною ідею стратегії у зазначеному аспекті доцільно вважати таку: від креативного педагога-вихователя - до креативного вихованця.

Перспективи подальшого дослідження окресленої проблеми вбачаємо у площині розвитку у дітей передшкільного віку соціальних навичок через культування їхньої творчості у просоціальній діяльності.

\section{СПИСОК ВИКОРИСТАНИХ ДЖЕРЕЛ}

[1] Гончаренко С. У. Український педагогічний енциклопедичний словник. Вид. друге, доп. й виправлене. Рівне: Волинські обереги, 2011. 552 с.

[2] Гриненко І. В. Технологія креативного багаторівневого кодування інформації та її застосування у навчанні студентів гуманітарного профілю. Наукові записки ТНПУ ім. В. Гнатюка. Серія: Педагогіка. 2006. № 4. С. $211-217$.

[3] Енциклопедія для фрахівців соціальної сфери / За заг. ред. І.Д.Звєрєвої. Друге вид. К., Сімфрерополь: Універсам, 2013. 536 с.

[4] Лисенко Н. В. Кирста Н. Р., Лазарович Н. Б. Педагогіка українського дошкілля. У З-х ч. ч. З.: Навч. пос. К., Вид. Дім «Слово», 2016. 376 c.

[5] Лиценко І. Дошкільна освіта і глобалізація. Пріоритетні напрямки виховання дошкільнят. Дошкільне виховання. 2016. № 3. С. 3-9.

[6] Предборська І., Ганоба С. Творчість як складова якості освіти. Філософсько- методологічні засад підвищення якості вищої освіти України: європейський вимір: кол. монографія / кер. авт. кол. В.Андрущенко. К: Пед. думка, 2012. С. 76 - 91.

[7] Психологічна енциклопедія / автор-упор. О. М. Степанов. К: «Академвидав», 2006. 423 с.

[8] Філософський енциклопедичний словник / голова редколегії В. І. Шинкарук. К: Абрис, 2002. 742с.

\section{REFERENCES (TRANSLATED AND TRANSLITERATED)}

[1] Honcharenko S.U. Ukrayins'kyy pedahohichnyy entsyklopedychnyy slovnyk (Ukrainian Pedagogical Encyclopedic Dictionary). Vyd. druhe, dop. y vypravlene. - Rivne: Volyns'ki oberehy, 2011. 552 s. (in Ukrainian)

[2] Hrynenko I.V. Tekhnolohiya kreatyvnoho bahatorivnevoho koduvannya informatsiyi ta yiyi zastosuvannya u navchanni studentiv humanitarnoho profilyu (The technology of creative multilevel coding of information and its application in teaching students of the humanitarian profile). Naukovi zapysky TNPU im. V. Hnatyuka. Seriya: Pedahohika. 2006. № 4. S.211 - 217. (in Ukrainian)

[3] Entsyklopediya dlya fakhivtsiv sotsial'noyi sfery (Encyclopedia for professionals in the social sphere) / Za zah. red. I. D. Zvyeryevoyi. K., Simferopol': Universam, 2013. 536 s. (in Ukrainian)

[4] Lysenko N.V. Pedahohika ukrayins'koho doshkillya (Pedagogy of the Ukrainian preschool). UZ - khch., ch. Z. : Navch. nos. / N.V. Lysenko, N.R. Kyrsta, N.B. Lazarovych. K., Vyd. Dim «Slovo», 2016. 376 s. (in Ukrainian)

[5] Lytsenko I. Doshkil'na osvita i hlobalizatsiya. Priorytetni napryamky vykhovannya doshkil'nyat (Preschool education and globalization. Priority directions of upbringing children of preschool age). Doshkil'ne vykhovannya, 2016. № 3. S. 3-9. (in Ukrainian)

[6] Predbors'ka I., Hanoba S. Tvorchist' yak skladova yakosti osvity (Creativity as a component of the quality of education). Filosofs'ko-metodolohichni zasady pidvyshchennya yakosti vyshchoyi osvity Ukrayiny: yevropeys'kyy vymir: kol. monohrafiya / ker. avt. kol. V. Andrushchenko. K: Ped. dumka, 2012. S. 76 - 91. (in Ukrainian)

[7] Psykholohichna entsyklopediya (Psychological Encyclopedia) / avtor - upor. O. M. Stepanov. K: «Akademvydav», 2006. 423 s. (in Ukrainian)

[8] Filosofs'kyy entsyklopedychnyy slovnyk (Philosophical Encyclopedic Dictionary) / holova redkolehiyi V.I.Shynkaruk. K: Abrys, 2002. 742 s. (in Ukrainian) 